\title{
Assessment focus on essay of university students: the case between language- and non-language based courses in two private universities
}

\author{
Mari Karen L Gabinete
}

\author{
Correspondence: \\ karen.gabinete@gmail.com \\ Department of English \& Applied \\ Linguistics, De La Salle University - \\ Manila, 2401 Taft Avenue, 1004 \\ Manila, Philippines
}

\begin{abstract}
Assessing students' written output has always been a daunting task for Language teachers in the higher education. They do not only need to provide feedback on grammar and mechanics but also on content. Similarly, discipline-based or non-Language teachers face a host of challenges but are generally more disposed to providing feedbacks which are more focused on content rather than on form. However, it may not be the case for these two groups of teachers. The preference and style in giving of feedback by twenty professors in two private universities in the Philippines were investigated by examining the actual essay of their students after comparing the result against their self-report. The data had shown that contrary to what was revealed in their self-report, most Language teachers focus more on form while non-Language teachers gave unclear feedback if not none at all. Moreover, the teachers from two universities differ in the amount and focus of feedback and the type of required essay primarily due to syllabus content. Despite the difficulty of assessing students' literacy using writing task as a tool, teachers ought to provide feedback based on a prior discussed rating scale without compromising form and/or content in order to raise the level of writing proficiency of university students.
\end{abstract}

Keywords: Corrective feedback, Language teacher, Non-language teacher

\section{Background}

Assessment is an integral element of education. It is vital that students' work are assessed whether formally or informally so that teachers and/or administrators can make informed decisions in order to improve or revise curriculum content or to effect necessary pedagogical adjustments to meet the demands of the learners. The overarching purpose, however, of assessment in education is to measure or to determine whether or not students have learned or mastered a skill or concept in preparation for the challenges that they will encounter in the 'real' world. As such, literacy is measured in multiple ways but seems problematic especially when assessment is unclear, meaning it is not based on a clearly specified grading system or in the case of performancebased assessment, rating scale. A specific case is the use of essay writing to assess student literacy in content areas.

Test experts say that unlike other forms of assessments like true/false or fill-in-theblank and other objective type of tests, essay tests raise the level of students' thought processes and creativity (Arends, 1998). This form of evaluation allows creative 
expression of ideas while putting forward their thoughts clearly and effectively. While objective-based questions measure students' recall ability, essays, on the other hand, test application of learned skills and concepts in multiple ways. In responding to essay, students must not only retrieve and repeat facts that they have stored in their 'memory bank' but must show an understanding of the topic.

Granting that teachers in all content areas all agree on the usefulness of essays, the challenge for teachers-especially the language teachers-is the assessment of these essays where the painful reality is that teachers in the higher education have an average of thirty students of multi-language-proficiency per class and assigned a minimum of six classes. The task is less tedious for non-language-based teachers, because in order to measure students' learning in content areas other than language, they could easily utilize multiple-choice, true/false, fill-in or matching type of tests. Since assessment is an important issue in education, provision of feedback on essays of students is an integral element of the teachers' pedagogy and should be clearly incorporated in the curriculum. Bernstein (1990) calls this the 'visible pedagogy'. This aims to raise the consciousness of learners in the hope of correcting errors and eventually attain desired learning outcome. But such is not the consensus of all scholars in the field of second language writing. According to Joughin (2008) as cited in Li (2008), the three primary roles of feedback are to support the learning process, to judge current achievement, and to maintain disciplinary and professional standards. However, the three roles may not function as expected and could be viewed differently because: "feedback may not support improvement, judgment may not be fair, and disciplinary standards are often unclear or even confusing to students" (Joughin, as cited in Li, 2008, p.137).

\section{Related literature}

\section{Corrective feedback on writing of second language learners}

Joughin's view of feedback, in the forgoing paragraph, is not far from the strong assertion of Truscott (1996, Truscott 2007) on the ineffectiveness of corrective feedback. Despite their negative stance, Ferris, etal. (Ferris \& Roberts, 2001; Ashwell, 2007; Fathman and Whalley, 1990; Kepner, 1991) continue to hold high hopes that corrective feedback can help improve the writing skill of second language learners. However, second language scholars' researches on writing reveal a" constellation of moderating variables that could make a difference regarding corrective feedback effectiveness" (Russell and Spada 2006). The efficacy of corrective feedback (CF henceforth) has been a subject of much controversy (Truscott, 1996; Ferris, 2009) and which continues to generate an exchange of contrasting discourse between the advocates and non-believers of feedback correction, most especially the feedback which pays attention to grammar correction. In his article The effect of error correction on learners' ability to write correctly, Truscott (2007) examined the findings of Chandler (2003), Ferris (2003), Lalande (1982), et al., to find the best estimate of the overall effect of correction on accuracy and to determine an upper limit on how helpful correction might be through a meta-analysis, relying on the measure most widely used, Cohen's $d$. The conclusion gleaned from his investigation revealed that the best estimate is that correction has a small harmful effect on students' ability to write accurately and that he can be ninety-five percent confident that if it actually has any benefits, they are very small. 
The study of Truscott (2007) emphasized the effect of correction on accuracy without regard to whether any type of feedback is the more effective method. This prompted Ashwell (2007) to examine the best method of feedback: content feedback on early drafts followed by form feedback on later drafts, the reverse pattern, mixed pattern or no feedback. Advocates of a process writing approach to second language writing pedagogy suggest that teachers should focus on content on early drafts before focusing on form on later drafts. Ashwell experimented on four mentioned patterns of teacher feedback and found that the recommended pattern of content feedback followed by form feedback is not superior to the reversed pattern or to a pattern of mixed form and content feedback.

In response to Ferris' (2003) challenge to define the parameters of the research design and methodology and in order to isolate the effectiveness of feedback, Guenette (2007) examined whether feedback is pedagogically correct. In her 2007 article, issues about whether the experiment considered the proficiency level of the participants, the type of treatment whether the feedback is focused on form or focused on content, on whether the corrections were direct or indirect, on whether the experiment was a one-timeoccurrence or longitudinal and lastly, Guenette questioned whether there was any incentive or motivation provided to the participants. After reviewing numerous experiments, she argues that a generalized conclusion may not be arrived at as yet, because these studies seem to have not considered other variables that may have contributed to the conflicting results gleaned from these investigations. These variables include research design and methodology. From this standpoint, Guenette (2007) suggests creating an ideal experiment scenario where students, belonging to almost the same proficiency level in terms of speaking and writing in the second language, are given ample time to learn from the corrections given by their teachers. Other variables that stand to confound the result of this experiment may be the type of feedback given, whether content-focused or form-focused, and the classroom context. Lastly, Guenette emphasized the importance of motivation of the students in wanting to improve their writing skills in a study that questions the pedagogical correctness of feedback at the same time discussing the research design issues in studies of feedback writing.

The above research studies dwelt mostly on feedback in the perspective of the writer and the feedback provided by the teacher. Not too many examined the teacher's selfassessment of the type and amount of feedback that they provide to students. All these three aspects were investigated by Montgomery and Baker (2007), involving the compositions of ninety-eight students at Brigham University ELC. The study revealed that teachers were not completely aware of the amount of local and global issues throughout the writing process although students perceived receiving more feedback than teachers perceived giving.

\section{Writing and corrective feedback in content areas}

Except for Language-based courses, writing is often neglected in other content areas like Science, Social Studies and especially in Mathematics, yet, teachers of these disciplines often require their students to write reflections, journals, and critiques, as a form of evaluation. In Mathematics for example, writing can help make students sense of the processes and help teachers understand what students are learning. In Social Studies, students must think critically about the events and issues they are studying. Here, topics can be explored by reporting, exposition, narration 
and argumentation. Similarly, connecting science and writing is an opportunity for teachers to examine the students' knowledge and understanding of basic science concepts and ideas.

Content area teachers' response to writing of their students is an area in research that is unexplored. Santos (1988), Leki (1991) and Hylland (1998) and other scholars mentioned elsewhere in this article are some of the few scholars whose work on feedback correction in content areas help fill the gap on the dearth of researches in this specific area which aim to scaffold scholars in understanding the preferences and style of teachers in the content areas in as far as CF is concerned. Also, a number of studies suggest that the overall grades teachers in higher education assign on papers of students have more to do with typical ESL errors. A study that found conflicting result was that of Santos (1988) who reported that content-area instructors in the U.S. tend to be reasonably tolerant of grammatical errors made by non-natives, and much less tolerant of problems with content. A recommendation was thus proposed that language teachers re-align their pedagogical instruction to target the content of writing instead. As regards the focus of CF, a study on the academic writing of 9 Mexican postgraduate students in British universities revealed that discipline-specific professors from Business, Systems, Education and Biology paid more attention to content in the students' writing than they did to mechanics or form (Camps and Salisbury, 1999; Camps, 2000).

In 2004, Zhu reported in his study that faculty focused on aspects related to content of their disciplines rather than on form although CF on form was likewise given importance. A similar result was obtained in the studies of (Vann et al. 1984), Santos (1988), Janopoulos (1992), and Song and Caruso (1996) who found that content becomes the main focus of disciplined-specific professors which therefore suggested that non-native speakers in English-speaking universities should give importance to content, and that non-native speakers admitted that they prefer feedback on both content and form to help them improve their writing skill (Camps \& Salisbury, 1999; Camps, 2000; Ferris, 2002). These studies, however, were carried out in US and British universities; hence a general statement cannot be derived if applied in Philippine setting. In fact, there seems to be an absence of research in this area which could possibly corroborate the findings that this article attempted to carry out.

In Hyland (2003), teachers were found to consider not only the errors they find on their students' papers but also the students responsible for them, where comments are based on their existing relationship with the students and the available information that relates to these students, e.g. background, needs, and preferences (Janopoulos, 1992). To this Leki (1991) suggests that second language teachers may be 'fulfilling several different and possibly conflicting roles' as they respond to student writing.

\section{Context of the study}

The context of the study is not to focus on corrective feedback as meant to comment on the writing skills of second language learners but to investigate the disposition of language and non-language professors in their provision of feedback on the essay of their students. For the purpose of the study, faculty members were classified as Language and Non-Language. Here, Language professors are those who teach communication skills, e.g. English Communication skills, Speech Communication, Technical/Research Writing, Filipino, while Non-Language professors are those who are in the area of Science/Math, Theology, Philosophy, Psychology, Economics and Business. 
With the purpose of identifying professors' views and actual use of feedback as reflected in teachers' self-assessment and their CF on students' essays in both language- and nonlanguage-based courses, I have attempted to embark on a quantitative-qualitative research using a small sample of respondent-students and teachers to find out the assessment focus of language and non-language professors on the writing tasks of students. Also, an investigation of the students' written outputs was undertaken to determine whether teachers provide corrective feedback. In addition to the provision of written feedback, the inquiry also paid attention to the type of feedback given by language- and non-language-based teachers to validate their self-assessment whether their written responses are focused on form (grammar, spelling, punctuation, capitalization) or focused on content (meaning, content, organization). On whether there was a difference in the results between two learning institutions, comparison of responses were carried out for both students and professors, and the actual feedback as reflected in the essay of students in two private universities. This article reports the beliefs and practices of language and non-language professors on the provision of corrective feedback and the perception of students on written comments or grades awarded on their essays in two private universities.

To investigate the assessment focus on essays, a survey was conducted in two leading higher learning institutions in Manila, Philippines where twenty professors in different content areas were surveyed. Similarly, students were huddled in small group discussions in which their opinions were sought about the difference of CF between the groups of professors. In addition, these students were asked to reveal their preferred CFs and reasons for these preferences. Twenty sample essays from students were utilized as primary data to determine whether professors in language and non-language -based courses focus their CF on form or on content. In the result section of this paper, the schools were labelled as University A and University B.

A strong hypothesis that can be formulated around literature relating to language teaching is that language professors focus more on form or local issues when giving written feedback while non-language professors focus more on content, ideas, and organization when giving CF on essays of students. This could be interpreted by the fact that language professors believe that it is more their responsibility to check the grammar of the students than it is of the non-language faculty. This hypothesis is based on the findings of Leki (2006) which suggest that students prefer several comments especially on local issues (e.g. Cohen, 1987 as cited in Leki, 2006), however, the analysis of actual teacher feedback suggests that teachers gave little feedback on global issues. The research of Leki (2006) demonstrates a difference in the type and amount of feedback given on disciplinary-based papers, papers written for their specific field of study.

In order to substantiate the hypothesis, a survey supplemented by small-group informal interviews were conducted inquiring whether teachers give essays as part of classroom activity or assignment and if they do, are the corrections more focused on local or global issues. Also, actual CF of teachers were analyzed by classifying and clustering CFs as reflected on essays of students. Specifically, the paper sought answers to the following research questions:

1. What is the most common type of essay that language and non-language professors in the tertiary level require their students to write? 
2. How do Language and non-Language professors differ in the type of feedback given to students as revealed in:

a) self-assessment and

b) actual CF on students' paper?

3. How do students view the CF provided by professors in Language- and NonLanguage-based courses in terms of focus and preference?

\section{Methods}

The study was modeled after the research carried out by Montgomery and Baker (2007) at Brigham University in which self-assessment of teachers' corrections given to students on their essays were compared with students' assessment on feedback given by teachers. Also, the said study determined the focus of corrections of teachers in terms of whether the corrections are global, focused on meaning, or local, focused on grammar. The researcher modified the study by comparing the self-assessment of Language and non-Language teachers on the feedback that they provide to students' essays through a survey, interview and an investigation of students' essays. An eightitem questionnaire (see Additional file 1) was given to twenty faculty in the higher education, to determine the type of essay they require their students to write, the focus of corrections, whether a revision is required and whether there was an improvement in the essay after feedback was provided. To determine whether the self-assessment of teacher participants corresponds with the actual corrections provided on essay of students, sample essays of students from language- and non-language-based courses in two private universities were collected, coded, analyzed and compared.

\section{Participants of the study}

Twenty college level (12 male, 8 female) teachers and twenty college students were included as participants in the study. The teachers are faculty members of two private universities in the national capital region of the Philippines. They are, for the purpose of the study, classified as language and non-language teachers. Language teachers are those who teach English Communications Skills, Technical/Research Writing, Technical Writing with Business Application, Art, Man, \& Society (Humanities), Philippine Literature, World Literature, and all equivalent subjects in Filipino. On the other hand, non-language teachers are the teachers who teach Mathematics/Science, Social Science, Business, Accountancy, Psychology and Economics.

These teachers teach in the languages department and eleven teach courses from different departments and colleges e.g. Science/Math, Psychology, Accountancy, Economics, Business. One of these twenty college level teachers teaches both Japanese language and courses in Psychology. However, for purposes of classification, the faculty was considered as a non-language teacher because the sample essay that was given by this particular teacher was an output in her Psychology class.

\section{Data-gathering procedure}

Teacher self-assessment data were collected from survey using an 8-item questionnaire to answer research question 1 and 2 a however, it is necessary that actual essays (one student sample essay from each teacher) be examined to answer research question $2 \mathrm{~b}$. The survey was carried out in summer of 2010 in university A and at the end of Term1 
(September) academic year 2011-2012 in university B. Students' outputs include art criticism, answer to essay test questions, narrative essay, reaction paper, reflection paper and argumentative essay. In addition to teacher self-assessment and students' essays, the researcher conducted an informal interview among students during the same period of time when surveys were administered.

\section{Research instrument}

An 8-item questionnaire was utilized to gather information about the facultyparticipants and their assessment focus on essay of college students (see Additional file 1). The questions were prepared by the researcher to seek answer to the research questions. Item 1 provides the profile of the participant in relation to the course/s they teach. Item 2 determines whether the participant is a language or non-language teacher. Items 3 and 5 provide information on whether they ask students to write essays as part of classroom activity or assignment and if they do, what type of essay is commonly required.

To answer research question number 2a, item no.6 asks the participants what the focus of their correction is, whether it is on form - focused on grammar, spelling, punctuation, capitalization, or on content - focused on meaning, content, and organization.

In answering research question no. $2 \mathrm{~b}$, the researcher analyzed the sample essays by:

1. coding the students' output from L1 to L11 for Language and NL12 to NL20 for non-Language with each letter-number code corresponding to a sample essay where $\mathrm{L}$ stands for Language and NL stands for non-Language. In addition and for the purpose of clarity, the capital letters A and B stand for university A and university B respectively.

2. copying the exact specific teacher correction of both Language and non-Language (Appendix A);

3. determining whether corrections are local or global for both Language and non- language

4. comparing corrections of Language and non-Language teachers

5. following Mahmoud (2000) classification of corrections, the following were adopted and modified to identify the clarity of CFs e.g. a:

a. mere indication of the location of error by enclosing or underlining word/s is classified as unclear; assigning of score with no feedback is likewise regarded as not clear.

b. writing correction codes or symbols pays more attention to form rather than content

c. giving rules and explanations leading to the correct forms are similarly focused on form as well as direct correction by writing the correct forms

d. marginal comments questioning ideas pays attention to content

Items 7 and 8 are questions answerable by yes or no referring to students' revisions after teacher corrections are given and improvement in writing skills after revision was made. Since there were no data by which the researcher could investigate whether there was an improvement in the essay of students after corrections were made, these pieces of information were merely based on perception as they were data from selfassessment of teachers.

Item 9 gives opportunity for the participants to provide information about other forms of feedback aside from the ones suggested by the questionnaire. 
An interview with the twenty students provides responses to answer research question 3 which sought to investigate the view of students on the difference between language and non-language teachers in terms of the focus of corrective feedback on essays and their CF preferences (see Table 1).

\section{Results}

Table 2 describes the profile of participants in two universities in terms of the subject area whether the participant is a language or non-language teacher, the gender, age and the particular course that each participant handles. The study involved thirteen female and seven male teachers eleven of whom are language teachers while nine are non-language teachers. In terms of age, nine of the twenty faculty from both the language and non-language are in their $20 \mathrm{~s}$, five, in their $40 \mathrm{~s}$, four, in their $50 \mathrm{~s}$, and two are in their $30 \mathrm{~s}$.

The data in Table 3 reveals the type and focus of essay of both language and non-language teachers as indicated in self-assessment report. In relation to the most common type of essay required by language teachers, it is interesting to note the difference between the two universities. While university $A$ requires a mix of various types of essay, university B requires very specific essay types

Table 1 Students' perception and preference on CF of teachers

\begin{tabular}{|c|c|c|}
\hline Language & Non-language & Preference \\
\hline $\begin{array}{l}\text { Some language teachers are strict } \\
\text { about the form. Most focus on } \\
\text { both form and content. }\end{array}$ & $\begin{array}{l}\text { Non-language teachers focus } \\
\text { more on correct answer }\end{array}$ & $\begin{array}{l}\text { I prefer writing in non-language } \\
\text { because I will not worry on the } \\
\text { correct structure of my essay }\end{array}$ \\
\hline $\begin{array}{l}\text { Since the grammar and spelling are } \\
\text { important in language, they focus } \\
\text { on form }\end{array}$ & $\begin{array}{l}\text { In non-language, understanding } \\
\text { of the lesson is more important }\end{array}$ & $\begin{array}{l}\text { I like teachers to correct my essay, } \\
\text { grammar, spelling }\end{array}$ \\
\hline $\begin{array}{l}\text { corrects spelling, punctuation, word } \\
\text { choice and grammar }\end{array}$ & questions thoughts on that topic & $\begin{array}{l}\text { I appreciate feedback on form but } \\
\text { I prefer comments of non-language } \\
\text { because I care more on the idea }\end{array}$ \\
\hline $\begin{array}{l}\text { focus more on grammar, spelling, } \\
\text { scan through organization, and } \\
\text { check content. }\end{array}$ & $\begin{array}{l}\text { focus less on spelling and } \\
\text { grammar; more on researched } \\
\text { ideas }\end{array}$ & $\begin{array}{l}\text { both teachers should remember } \\
\text { that grade should relate more } \\
\text { about the subject }\end{array}$ \\
\hline $\begin{array}{l}\text { Language teachers tend to be } \\
\text { writing perfectionists }\end{array}$ & $\begin{array}{l}\text { Non-Language also consider } \\
\text { spelling of certain terms but } \\
\text { not too particular on spelling } \\
\text { of common words }\end{array}$ & $\begin{array}{l}\text { I prefer feedback of non-language } \\
\text { because I can freely express my } \\
\text { thoughts }\end{array}$ \\
\hline $\begin{array}{l}\text { concentrates more in grammar and } \\
\text { spelling }\end{array}$ & $\begin{array}{l}\text { gives consideration on spelling } \\
\text { and grammar and concentrates } \\
\text { more on content }\end{array}$ & $\begin{array}{l}\text { I prefer feedback from non-language } \\
\text { because I often misspell words and } \\
\text { sometimes get mixed up with } \\
\text { grammar which hinders me from } \\
\text { making good essay }\end{array}$ \\
\hline $\begin{array}{l}\text { Most Language teachers tend to } \\
\text { focus more on how sentences are } \\
\text { constructed to determine students' } \\
\text { grammar proficiency }\end{array}$ & $\begin{array}{l}\text { Non-Language teachers tend } \\
\text { to stick to their given topic } \\
\text { disregarding most of the time } \\
\text { proper grammar because the } \\
\text { words carry vital information } \\
\text { for the course }\end{array}$ & $\begin{array}{l}\text { I prefer that teachers judge papers } \\
\text { for the content not how they write } \\
\text { because not all students have } \\
\text { mastered the English language. } \\
\text { Personally, I prefer that teachers be } \\
\text { meticulous in grammar to allow } \\
\text { each student to improve in their } \\
\text { writing skills. }\end{array}$ \\
\hline $\begin{array}{l}\text { Language profs tend to be overly } \\
\text { critical about grammar, e.g. tense, } \\
\text { spelling, form outweighs content }\end{array}$ & $\begin{array}{l}\text { Tend to review the content and } \\
\text { overall projection of the writer's } \\
\text { idea }\end{array}$ & $\begin{array}{l}\text { Writing assessment is effective if } \\
\text { profs provide feedback, however, } \\
\text { students do not want to see } \\
\text { corrections most of the time } \\
\text { because frankly, it makes us feel } \\
\text { stupid. }\end{array}$ \\
\hline
\end{tabular}


Table 2 Profile of participants

\begin{tabular}{|c|c|c|c|c|c|c|c|c|c|c|c|c|c|c|c|}
\hline \multirow[b]{2}{*}{ Lang (L) } & \multirow[b]{2}{*}{ Gender } & \multicolumn{6}{|c|}{ University A } & \multirow[b]{2}{*}{ Lang (L) } & \multirow[b]{2}{*}{ Gender } & \multicolumn{6}{|c|}{ University B } \\
\hline & & $\overline{\text { Age }}$ & Course & Non-Lang (NL) & Gender & Age & Course & & & $\overline{\text { Age }}$ & Course & Non-Lang (NL) & Gender & Age & Course \\
\hline AL1 & $\mathrm{F}$ & 54 & Humanities & ANL7 & M & 35 & Psychology & BL1 & $\mathrm{F}$ & 40 & EnglishCommskills & BNL6 & $\mathrm{F}$ & 40 & Economics \\
\hline $\mathrm{AL2}$ & M & 26 & Filipino & ANL8 & $\mathrm{F}$ & 27 & Psychology & BL2 & $F$ & 38 & EnglishCommskills & BNL7 & $M$ & 26 & ManaOrg \\
\hline AL3 & $\mathrm{F}$ & 55 & Filipino & ANL9 & M & 28 & Business & BL3 & $\mathrm{F}$ & 28 & EnglishCommskills & BNL8 & $\mathrm{F}$ & 28 & Science \\
\hline AL4 & $\mathrm{F}$ & 56 & Filipino & ANL10 & $\mathrm{F}$ & 52 & SocScience & BL4 & $M$ & 24 & EnglishCommskills & BNL9 & $M$ & 24 & IntroPsy \\
\hline $\mathrm{AL5}$ & $\mathrm{F}$ & 42 & TechWrit & ANL11 & $\mathrm{F}$ & 45 & SocScience & $\overline{B L 5}$ & $M$ & 32 & Filkomu & & & & \\
\hline AL6 & $\mathrm{F}$ & 45 & Literature & & & & & & & & & & & & \\
\hline
\end{tabular}


Table 3 Teacher self-assessment \& type of essay required and focus of CF

\begin{tabular}{|c|c|c|c|c|c|c|c|c|c|c|c|}
\hline \multicolumn{6}{|c|}{ University A } & \multicolumn{6}{|c|}{ University B } \\
\hline Tchr & Type of essay & Focus of CF & Tchr & Type of essay & Focus of $\mathrm{CF}$ & Tchr & Type of essay & Focus of CF & Tchr & Type of essay & Focus of $\mathrm{CF}$ \\
\hline AL1 & Reflection & content & ANL1 & Argument & content & BL1 & expo/argu & form/content & BNL6 & reflection & Content/form \\
\hline AL2 & Expository & Form/cont & ANL2 & Argument & content & BL2 & expo/argu & form/content & BNL7 & analytical & Content \\
\hline AL3 & Narrative & Form/cont & ANL3 & Argument & content & BL3 & expo/argu & content & BNL8 & narrative & Content \\
\hline AL4 & Expository & content & ANL4 & Argument & content & BL4 & expo/argu & content/form & BNL9 & expository & Content \\
\hline AL5 & Bus.corresp & Form/cont & ANL5 & reflection & content & BL5 & expo/argu & content & & & \\
\hline AL6 & Lit.analysis & Form/cont & & & & & & & & & \\
\hline
\end{tabular}


which are expository and argumentative. As revealed in the interview, language teachers in university A follow a syllabus (English/Filipino) covering areas in grammar/reading/writing while the language syllabus in university B is split between grammar/reading/viewing and writing component. Hence, two teachers team teach communication skills in university B where specific essay types are required as major essays in the writing component. In this study, the participantfaculty of university B handles the writing component. Students in the writing component subscribe to a process-approach and consequently are given sufficient time to improve and complete their essay. Conversely, the course Basic Communication Skills (English and Filipino) in university A is being handled by one faculty. Needless to say, language faculty of university A do not have much time to write corrections on students' essay because of the other language topics that they needed to cover.

On the other hand, majority of non-language teachers in university A require their students to respond to controversial issues; hence, argumentation is the most common type of paper. Similarly, non-language-based teachers in university B provide opportunities for their students to respond to controversial topics, but they differ in their writing output requirements. BNL6 (Political Science), for example, requires her students to write reflection, concept, and analytical papers and to create and design a news magazine, video, website and blog. She however did not state which of these projects are to be done individually or by pair/group.

As regards the focus of correction as revealed in the self-assessment report, none of nonlanguage teachers pay attention to form when providing CF on papers of students while language teachers understandably focus their CF on both form and content (70\%) and only three out of the ten (30\%) language teachers report giving emphasis on content alone.

The data presented in Table 4 reveals the type and focus of CF provided by the teacher upon examination of sample essays of students. These pieces of information show the correspondence between self-assessment report and provision of CF on various essays of students. As gleaned from the data, most language teachers, four out of ten, pay attention not on content but on form (40\%) and an almost equal number, three out of ten (30\%) give importance to both form and content, contrary to their claim that content should be given more focus. Of the ten teachers, two focused on content while the remaining two provided unclear CF. A feedback that stood out from all CFs analyzed was the one provided by a non-language professor from university $\mathrm{B}$ which neither focus on form nor content but more on the student. This can be

Table 4 Focus of corrections based on actual students' essay

\begin{tabular}{lccccccr}
\hline \multicolumn{3}{c}{ University A } & \multicolumn{4}{c}{ University B } \\
\hline Tchr & Focus of CF & Tchr & Focus of CF & Tchr & Focus of CF & Tchr & Focus of CF \\
\hline AL1 & content & ANL7 & content & BL1 & Content & BNL6 & content \\
\hline AL2 & form & ANL8 & form/content & BL2 & content/form/student & BNL7 & content \\
\hline AL3 & form & ANL9 & unclear & BL3 & content/form & BNL8 & content \\
\hline AL4 & form & ANL10 & unclear & BL4 & content/form & BNL9 & student \\
\hline AL5 & form & ANL11 & content & BL5 & Unclear & & \\
\hline AL6 & unclear & & & & & \\
\hline
\end{tabular}


interpreted as being influenced by the nature of the course. In the case of BNL9, who is teaching Introduction to Psychology, the professor required a reflective essay.

Below are sample CFs of different types: form, content, both form/content, and unclear CFs.

Focused on form:

The teacher focused on local errors such as spelling [dyip/dyipni instead of jeep/jeepney], capitalization [Ako instead of $a k o$ ] and choice of word [Sa madaling salita instead of Sa isang salita, $n g$ instead of $n a$ ]. (AL2 professor)

Teacher pays attention to format of paper e.g. margin, spacing, indentions, this being a technical writing course. (AL5 professor)

Focused on content:

Since sample ANL7 is a response to prompt, the teacher wrote comments on student's essay not to improve writing skill but to correct line of reasoning of the student [changes,] teacher responds: [You should have started w/changes that occur for both sexes then, you could discuss changes in boys \& then girls; talking not necessarily; this is a different thing]. (ANL7 professor)

Focused on both form/content:

Sample from ANL8 is a response to essay prompt but unlike ANL7, the teacher provides local correction [the word councilor] was underlined and pointed to the correct spelling of the word counselor, [councilor that's politician], and global feedback such as underlining a phrase, e.g. a background [background only?].

(ANL8 professor)

Unclear feedback:

In sample from AL6, the teacher merely wrote a check mark on the first page of the student's essay and a smile symbol on the second page. A grade of 98/100 seems to indicate an excellent work.

Sample essay from ANL10 indicated neither a comment nor a correction. The essay was given a grade of 7/10.

It is interesting to note that professors from university B extend their CF beyond form and content and apparently create a dialogue between the teacher and the student. Sample of this type is illustrated below: (note: student's writing is underlined; teacher's CF is italicized)

drives me to take risks, teacher responds: [Because these 6 words are what you need now...]

outcomes that are uncertain, teacher comments: [So what do you choose? BIG? SMALL? It is like jumping hurdles in a track \& field event, will you jump the smaller hurdles $w / c$ you can easily maneuver or the BIGGER hurdles $w /$ greater risks of falling? Either way, what are you risking? what's the point of jumping small hurdles? big hurdles?]

I've done, every little change to this teacher responds: [Yes! good! OR could it be possible that when you take risks, you become normal? Because to fit in something normal is also theoretical, Perhaps, what you really wanted is to become a person who lives di ba? (2 sides of the same coin)] 
that lead to growth, be it by good or bad. [Because losses can't exist w/o gains... they

exist together... never apart...]

"what if" teacher encircles the phrase and writes: [This statement are for those who

have yet to learn their lesson....] (from professor BNL9)

The data gleaned from Table 4 show the disposition of teachers from University A where (see Appendix A) majority, i.e., 3 out of 5 or 60 percent of language teachers focused on local issues while majority, i.e., 4 out of 6 or 66 percent non-Language teachers were unclear about the feedback or corrections that they provided on students' essays. When compared, as revealed by actual students' essays and self-assessment of teachers' feedback/correction, there seemed to be a mismatch in the correction or feedback that they provided on students' essays. Language teachers' corrections focused more on local issues although self-assessment revealed that this group of teachers gave an equal emphasis on both local and global issues except for one teacher who indicated focusing on local issues. On the other hand, the non-Language teachers, as revealed by actual students' essays gave an unclear feedback if not none at all. The self-assessment, however, revealed that this group of participants also gave an equal emphasis on both local and global which was the opposite of what was revealed on the actual essays of students.

\section{Student's perception of teachers' CF}

The twenty students who wrote the essays assessed by faculty-participants were interviewed to find out their CF preference and whether there was any difference in the way language-based and non-language-based professors provide feedback on their essays. Table 1 presents a summary of responses as revealed by student-interviewees which are representative of majority responses.

\section{Discussion}

This study was undertaken to find out the assessment focus on essay of university students provided by professors in language- and non-language-based courses. Teacher interview and self-assessment were utilized to find out whether essay corrections were focused on form or content and validated by actual corrections on essay of students in higher education. Also, students' perceptions and preference were revealed from informal interview to further supplement the data and to raise teacher awareness on the effect of corrections on students.

\section{Form vs content; language vs non-language}

As shown in the result of the survey and actual corrections given on student' essays, there seems to have a contrast between the result of the two data. Language professors focus more on local issues when giving corrective feedback which supports this researcher's hypothesis that language teachers are more concerned in correcting the grammar of their students' essays. Teacher interview reveals however, that Language-based faculty from university A are burdened by topics to cover with one teacher handling the whole course, thus leaving them less time to scrutinize and write content-focused comments on essay of students whereas their counterparts from university B, who team teach the course with another faculty and subscribing to process approach to writing, are more disposed to make comments on both form and content. It is understandable that non-language faculty focus more on content over form, as they are generally 
assessing the critical and analytical thinking skills of their students as evidenced by the type of essay they require their students to write, which are mostly reflective essays. Ideally, this type of essay, particularly the self-reflection, allows students to participate in the assessment process (Boud, 1989) and evaluate their own growth to understand not only what they know or expect to know but also what they value about learning. Although, it may be wrong to generalize that non-language professors are not concerned with the grammar of their students' essays because the data from survey revealed that they focused on both local and global issues, actual students' essay revealed an unexpected result. It was found that some non-language professors (university A) do not make clear feedback, if at all any correction was provided. An explanation that could be offered is the fact that majority of the non-language faculty (in study) from university A are burdened by the large class size (averaging 40) and number of classes (minimum of 7) assigned. In this light, an opportunity seems lost in the assessment of essay in Social Science as this discipline is generally concerned with concepts formation, scientific principles, inquiry processes, and critical thinking (Tamir \& Kempa, 2006). Conversely, it is inspiring to see that in university B, although a majority focus on form and content, two faculty from both language and non-language do extend their CFs beyond what traditional teachers provide. The essays of students become an opportunity for the teacher to reach out and create a correspondence with the student which concurs with the findings in the study conducted by (Janopoulos 1992).

\section{Students' perceptions and preference}

Students' perceptions reveal that language professors tend to be strict on writing conventions such as spelling, punctuations, word usage, grammar while non-language faculty focus more on checking the organization, meaning and content of the essay. As regards the preference, although majority of students seem to prefer corrective feedback provided by non-language professors, it is only because language professors expect much from their essay which hinders them from freely expressing their thoughts without regard for structure and form. Most Filipino students (in study) in the university still admit to not having completely mastered the skill of essay writing, hence, the fear of obtaining an average or even below average score in writing tasks. After all, essay scores (in study) are mostly influenced by the amount of corrections regardless of whether the writing task follows a process approach or a one-time writing output. This leads to the notion that essay grades seem to be driven more by teacher perception rather than by actual content or quality of their essays. It is not surprising therefore to see that majority of students interviewed prefer less feedback on form which contradicts findings (Leki, 1991; Schulz, 2001; Ferris 2002) that students welcome feedback on grammar to help improve their writing in English. Students in Language courses do not seem to appreciate the corrections because corrections are viewed as depreciation of their worth as students, i.e., students' worth is equivalent to their grade, the ultimate indicator of their academic performance. An evidence lending to this notion was revealed from interview with students where numerous correction, especially those focused on form, are viewed as (students do not want to see corrections most of the time because frankly, it makes us feel stupid) manifestation of incompetence. This revelation begs the question of whether there is a single standard of 'correctness', a challenge that continually confronts teachers in grading students' essay. 


\section{Students' essay after revisions}

Regarding the improvement of students' essays after corrective feedback was given and whether revisions were made, data from survey reveal that students' essays in language classes seemed to manifest more an improvement in writing skills compared to students' essays in non-language classes. This could perhaps be explained by the fact that corrections on the writing output of students were discussed in class since the subject is a language course. Non-language teachers may find it time-consuming to discuss these matters as they are more concerned with the subject matter at hand, leaving the task of correcting the writing skills of their students to language teachers (Leki, 2006).

Despite the questions of CF's effectiveness, teachers ought to continuously provide corrections on the essays of their students as part of teaching pedagogy to improve the writing skills (Leki, 1991; Schulz, 1996; Ferris, 2002) of their students in the second language no matter how complex and demanding the task of providing feedback is to the teachers. As to the question of the focus of feedback, most researchers have found that L2 writers still needed to have more of local corrections in the first drafts before they could develop a sensible essay. Ferris (2009) advised provision of feedback which focuses on both form and content. Students tend to give importance to form if feedback is focused only on form.

\section{Conclusion}

These discussions seem to be a call for challenge to language and non-language professors in the college level, however, only those dedicated and committed teachers will heed with an uncomplaining obedience. The sad reality remains that assessment of literacy using writing tasks as a tool is the most difficult to measure especially if the rating scale is not discussed with the students prior to the writing activity and if the language and nonlanguage professors do not have the same standard in assessing students' writing output.

The course of action recommended in view of the results of this study, despite the limited number of respondents and sample essays, is for both language and nonlanguage based courses to subscribe to a standard method of assessing the essay of students in which form vis-à-vis content is not compromised over the other, in order to raise the level of writing proficiency of college students. In addition, whether a faculty teaches a language- or non-language-based course, it is suggested that he/she undergoes a continuous workshop and/or training in assessing students' writing output whether feedback is focused on form or content or both form and content.

\section{Appendix A}

\section{Transcript of teacher feedback and/or corrections}

University A

Language

AL1 No correction was provided on this sample essay. The teacher merely underlined the words unity and religion but wrote Great reflection at the end of the student's essay.

AL2 Sample AL2 is a narrative essay. The teacher focused on local errors such as spelling (e.g. dyip/dyipni instead of jeep/jeepney), punctuation (e.g. Ako instead of ako) and choice of word (e.g. Sa madaling salita instead of Sa isang salita, $n g$ instead of $n a$ )

AL3 Sample AL3 was rendered invalid as a source of data because the output is not an essay but a poem; however, the teacher also wrote correction focused on local errors (e.g. mag-alintana instead of alintanain) 
AL4 The teacher focused on local errors such as choice of word (e.g. ipinataw instead of linagay, use of lower case for common nouns (e.g. pamahalaan instead of Pamahalaan), underlining foreign word to be italicized (e.g. middle class), and using proof reader's mark to indicate specific corrections.

AL5 Teacher pays attention to format of paper e.g. margin, spacing, indentions, this being a technical writing course.

AL6 In sample AL6, the teacher merely wrote a check mark on the first page of the student's essay and a smile symbol on the second page. A grade of 98/100 seems to indicate an excellent work.

University B

BL1 Sample BL1 is 3-page expository essay assigned a grade of 14/20. The following comments were provided on the first 2 pages of student's paper: p1: check marks on the right margin of the paper with the word okay, at the bottom of the $3^{\text {rd }}$ check mark are additional comments saying Please see my comments in your email like modern day nationalism! and an instruction Provide a conclusion!; p2: Teacher underlines a long clause and writes unclear on the margin, a whole paragraph is enclosed by a bracket with comment synthesize rephrase, teacher instructs student to delete a direct quote, and finally, another checkmark is seen on the last paragraph of page 2. Using above written evidence, BL1 is paying attention to content.

BL2 Sample BL2is an 8-page- documentary analysis which was given a grade of 14.5/20. 2 check marks reveal teacher'sapproval on first 2 paragraphs of p1. Last sentence underlined: he cannot be a complete credible source, teacher responds: why do you say this?

First 3 paragraphs of $\mathrm{p} 2$ was bracketed, teacher writes: more of a summary, where is your critique?

Teacher writes fragment opposite encircled phrases and therefore? after a paragraph in p6, a question mark after some phrases at the bottom; instances as response to student's "the opposing sides and their points were shown with supporting details."

BL5 Teacher assigns a grade of 4.0 (highest possible score) on paper and writes check marks on every item indicating a positive comment, but no detail is provided

\section{Non-language}

University A

ANL7 Since sample NL6 are answers to essay questions, the teacher wrote comments on student's essay not to improve writing skill but to correct line of reasoning of the student (e.g. changes, teacher responds: You should have started w/changes that occur for both sexes then, you could discuss changes in boys $\mathcal{E}$ then girls; talking not necessarily; this is a different thing. This type of feedback is focused on content.

ANL8 Sample ANL8, just like ANL7, is an answer to essay question but unlike the teacher in NL6, the teacher provides local correction (e.g. the word councilor was encircled and pointed to the correct spelling of the word counselor, councilor that's politician, and global feedback such as underlining a phrase, e.g. a background background only?

ANL9 Sample ANL9 are answers to essay questions. The teacher merely wrote a cross mark on the item that does not seem to get his approval. It is not clear whether correction is local or global.

ANL10 In sample ANL10, the teacher wrote neither a comment nor a correction. The essay was given a grade of $7 / 10$. 
ANL11 The corrections given by the teacher to sample NL11 was not clear. Questions were written but the teacher did not specify what is not clear in the student's answer. In the no. 2 item of the test, the teacher encircled the word codes which seem to indicate that there is an error in the encircled word.

University B

BNL7 (PoliSci/Eco) Sample BL7 is a concept paper. Opposite the objective section of paper(p1), teacher writes "Assessment of Political Leadership" is the Main Theme which clearly indicates the expected response and a check mark on an underlined word indicating a positive response, on $\mathrm{p} 2$, written on the right margin of the paper opposite a bracketed paragraph Pls. ensure that you apply Benchmark Indicator if your group is assessing political performance/political leadership. Thanks. None of teacher's comment pays attention to form rather she expects student to revise essay or include suggestion in future piece of work. It is a rare occurrence in students' essay to see a positive comment such as Thanks.

BNL8 (ManaOrg) The sample is an essay test where teacher apparently expects specific responses as indicated by encircling items Individualism \& Materialism with a corresponding question mark. Three samples of paper (checked by same teacher) reveals same way of providing CF. Clearly teacher pays attention to content. A grade of 85 is assigned on student's paper.

BNL9 (Science) BNL9 The teacher merely encircled the word ally which does not give a clear feedback.

BNL10(Psych) A grade of 17/20 is indicated on the top portion of this six-word memoir reflection paper entitled The risks are always worth it. Teacher does not repond to student's work but create a dialogue between teacher and student, e.g.

drives me to take risks, teacher responds: Because these 6 words are what you need now...

outcomes that are uncertain, teacher comments: So what do you choose? BIG? SMALL? It is like jumping hurdles in a track E field event, will you jump the smaller hurdles $w / c$ you can easily maneuver or the BIGGER hurdles w/ greater risks of falling? Either way, what are you risking? what's the point of jumping small hurdles? big hurdles?

I've done, every little change to this teacher responds: Yes! good! OR could it be possible that when you take risks, you become normal? Because to fit in something normal is also theoretical, Perhaps what you really wanted is to become a person who lives di ba? (2 sides of the same coin)

that lead to growth, be it by good or bad. Because lossess can't exist w/o gains. . they exist together... never apart. .

"what if" teacher encircles the phrase and writes: This statement are for those who have yet to learn their lesson...

\section{Additional file}

Additional file 1: Appendix A: Survey Questionnaire for Teachers.

Competing interest

The author declares that they have no competing interest.

Received: 6 March 2013 Accepted: 6 March 2013

Published: 2 April 2013 


\section{References}

Arends, R. (1998). Learning to teach (4th ed.). Singapore: The McGraw-Hill Companies, Inc.

Ashwell, T. (2007). Patterns of teacher response to student writing in a multiple-draft composition classroom: Is content feedback followed by form feedback the best method? Journal of Second Language Writing, 9(3), 227-257.

Boud, D. (1989). The role of self-assessment in student grading. Assessment \& Evaluation in Higher Education, 14(1), 20-30.

Camps, D, \& Salisbury, T. (1999). Faculty perceptions of EFL student writing. Online Journal for Teachers. Retrieved from http://esp-world.info.

Camps, D. (2000). Drawing on, adapting and recreating writing practices for their academic purposes: The case of six Mexican postgraduate students at four British universities. PhD dissertation: Lancaster University.

Chandler, J. (2003). The efficacy of various kinds of error feedback for improvement in the accuracy and fluency of L2 student writing. Journal of Second Language Writing, 12(3), 267-296.

Fathman, A, \& Whalley, E. (1990). Teacher response to student writing: Focus on form versus content. In B Kroll (Ed.), Second language writing: Research insights for the classroom (pp. 178-190). Cambridge: Cambridge University Press.

Ferris, DR, \& Roberts, B. (2001). Error feedback in L2 writing classes: How explicit does it need to be. Journal of Second Language Writing, 10, 161-184.

Ferris, DR. (2002). Treatment of error in second lanquage student writing. Ann Arbor: University of Michigan Press.

Ferris, D. (2003). Response to student writing: Implications for second language students. The Reading Matrix. Vol.8 (2), 2008. Mahwah, NJ: Lawrence Erlbaum.

Ferris, D. (2009). Responding to writing. In B Kroll (Ed.), Exploring the dynamics of second language writing (p. 122). New York City, NY: Cambridge University Press.

Guenette, D. (2007). Is feedback pedagically correct? Research design issues in studies of feedback writing. Journal of Second Language Writing, 16, 40-53.

Hyland, F. (2003). Focusing on form: Student engagement with teacher feedback. System, 21, 217-230.

Janopoulos, M. (1992). University faculty tolerance of NS and NNS writing errors: A comparison. Journal of Second Lanquage Writing, 1(2), 109-121.

Joughin, G. (2008). Assessment, learning and judgement in higher education. London: Springer.

Kepner, CG. (1991). An experiment in the relationship of types of written feedback to the development of second-language writing skills. Modern Language Journal, 75, 305-313.

Leki, I. (1991). The preferences of ESL students for error correction in college-level writing classes. Foreign Language Annals, 24, 203-218.

Leki, I. (2006). Negotiating socioacademic relations: English learners' reception by and reaction to college faculty Journal of English for Academic Purposes, 5, 136-152

Lillis, TM. (2001). Student writing: Access, regulation, desire. Literacies. UK: Routledge.

Li, J, \& Barnard, R. (2011). Academic tutors beliefs about and practices of giving feedback on students' written assessments: A New Zealand case study. Assessing Writing, 16(2), 137-148.

Mahmoud, A. (2000). Coded corrective feedback: In search of a compromise. TESL Reporter, 33(2), 10-17.

Montgomery, J, \& Baker, W. (2007). Teacher-written feedback: Student perceptions, teacher self-assessment, and actual teacher performance. Journal of Second Lanquage Writing, 16, 82-99.

Russell, J, \& Spada, N. (2006). The effectiveness of corrective feedback for the acquisition of L2 grammar. A metaanalysis of the research. In JM Norris \& L Ortega (Eds.), Synthesizing research on language learning and teaching (pp. pp. 133-164). Philadelphia: John Benjamins.

Santos, T. (1988). Professor reactions to the academic writing of non-native-speaking students. TESOL Quarterly, 22, 69-90.

Sheppard, K. (1992). Two feedback types: do they make a difference? Regional English Center Journal, 23, 103-110.

Song, B, \& Caruso, I. (1996). Do English and ESL faculty differ in evaluating the essays of native English-speaking and ESL students? Journal of Second Language Writing, 163-182.

Tamir, P, \& Kempa, RF. (2006). Cognitive preference styles across three science disciplines. Science Education, 62 (2), 143-152.

Truscott, J. (2007). The effect of error correction on learners' ability to write accurately. Journal of Second Language Writing, 16, 255-272.

Vann, R, Meyer, D, \& Lorenz, F. (1984). Error gravity: A study of faculty opinion of ESL errors. TESOL Quarterly, 427-440.

Schulz, RA. (2001). Cultural differences in student and teacher perceptions concerning the role of grammar instruction and corrective feedback: USA-Colombia. Modern Lanquage Journal, 85, 244-258.

doi:10.1186/2229-0443-3-5

Cite this article as: Gabinete: Assessment focus on essay of university students: the case between language- and non-language based courses in two private universities. Language Testing in Asia 2013 3:5. 